\title{
Cadmium accumulation in the snow crab Chionoecetes opilio
}

\author{
Claude Rouleau ${ }^{1, *}$, Charles Gobeil ${ }^{1}$, Hans Tjälve ${ }^{2}$ \\ ${ }^{1}$ Institut Maurice-Lamontagne, Ministère des Pêches et Océans, CP 1000, 850 Route de la Mer, Mont-Joli, Québec G5H 3Z4, \\ Canada \\ ${ }^{2}$ Department of Pharmacology and Toxicology, Swedish University of Agricultural Sciences, Biomedicum Box 573, \\ 75123 Uppsala, Sweden
}

\begin{abstract}
The aim of this work is to evaluate the significance of Cd uptake via food in the snow crab Chionoecetes opilio. We used in vivo gamma counting to measure the retention efficiency of a single dietary dose of ${ }^{109} \mathrm{Cd}(\mathrm{II})$ and follow elimination kinetics of the metal retained over a 5 mo period. Whole-body autoradiography was used to determine the fine-scale tissue distribution. The biological half-life of Cd retained in the body after the first $15 \mathrm{~d}$, which represented 26 to $52 \%$ of the ingested dose, ranged from 141 to $346 \mathrm{~d}$. Whole-body autoradiography showed that ${ }^{109} \mathrm{Cd}$ was distributed to all the tissues, highest concentrations being found in the hepatopancreas and gut, followed in decreasing order by antennal glands $\geq$ hemolymph $>$ gonads $>$ gills $\approx$ hypodermis $\approx$ muscle $>$ eye. We used these data and a reasonable estimate of $\mathrm{Cd}$ levels in benthic organisms of lower trophic levels living in the Estuary and Gulf of St. Lawrence to model the long-term dietary uptake of $\mathrm{Cd}$ in snow crab. Predicted concentrations in hepatopancreas and muscle agreed quite well with field data (predicted range 13.0 to $39.2 \mathrm{nmol} \mathrm{Cd} \mathrm{g}^{-1}$ and field range 3.5 to $24.1 \mathrm{nmol} \mathrm{Cd} \mathrm{g}^{-1}$ for hepatopancreas; predicted range 0.20 to $1.33 \mathrm{nmolCd} \mathrm{g}{ }^{-1}$ and field range 0.52 to $2.03 \mathrm{nmol} \mathrm{Cd} \mathrm{g}^{-1}$ in muscle). The similarity between experimentally based predictions and field data strongly suggests that diet is a major transfer route of Cd towards snow crab in the St. Lawrence.
\end{abstract}

KEY WORDS: Uptake $\cdot$ Food $\cdot$ Snow crab $\cdot$ Cadmium $\cdot$ Pharmacokinetics $\cdot$ Distribution $\cdot$ Whole-body autoradiography $\cdot$ In vivo gamma counting

Resale or republication not permitted without written consent of the publisher

\section{INTRODUCTION}

Cadmium is one of the trace metals for which spatial distribution in marine sediments exhibits the largest variations, both horizontally and vertically, as a result of natural diagenetic processes (Rosenthal et al. 1995, Gobeil et al. 1997) or pollution. The extent of the accumulation of sedimentary $\mathrm{Cd}$ in benthic sedimentdwellers and deposit-feeders has been shown to be related to the amount of labile $\mathrm{Cd}$ in the sediments (Lee et al. 2000a,b,c), which can then be transferred

\footnotetext{
*Present address: National Water Research Institute, Aquatic Ecosystem Protection Research Branch, 867 Lakeshore Road, PO Box 5050, Burlington, Ontario L7R 4A6, Canada. E-mail: claude.rouleau@ec.gc.ca
}

via food towards benthic predators of higher trophic levels, such as flatfish and decapod crustaceans.

Decapod crustaceans are well known accumulators of cadmium (Rainbow 1988, Ozretic et al. 1990, Everaarts \& Nieuwenhuize 1995, Kannan et al. 1995). Most of the research work published to date about $\mathrm{Cd}$ accumulation routes in large marine crustaceans, such as shrimp and crabs, has targeted the direct uptake of the metal from water (Bjerregaard 1985, 1990, 1991, Bjerregaard \& Depledge 1994, Martin \& Rainbow 1998, Rainbow et al. 1999). But uptake via food may also be an important route (Fowler 1982). Jennings \& Rainbow (1979) found that the crab Carcinus maenas accumulated $10 \%$ of the Cd available from its food, but could not estimate the relative importance of the dietary uptake route to the total $\mathrm{Cd}$ accumulation. In 
another study, Davies et al. (1981) determined the distribution of $\mathrm{Cd}$ within captive crabs (Cancer pagurus) exposed experimentally to Cd-contaminated food and water. They compared these experimental results with the distribution of $\mathrm{Cd}$ within field-collected crabs and concluded that the dominant uptake route of cadmium in situ was through the diet. However, in order to be able to assess $\mathrm{Cd}$ concentration in the tissues of a given decapod crustacean as a function of varying $\mathrm{Cd}$ levels in its food, a quantitative knowledge of the relationship existing between the two is required (Landrum et al. 1992).

The snow crab Chionoecetes opilio (Brachyura, Majidae), is a common predator on mud and sand-mud substratum in cold waters along the Atlantic and Pacific Canadian coasts (Bailey \& Elner 1989, Lovrich \& Sainte-Marie 1997), whose diet mainly consists of benthic crustaceans, echinoderms, polychaetes, molluscs (70 to $80 \%$ ), and demersal fish (10 to $15 \%$ ) (Brêthes et al. 1994, Lovrich \& Sainte-Marie 1997). In the present work, we studied the pharmacokinetics and tissue distribution of a single dietary dose of radiolabelled ${ }^{109} \mathrm{Cd}$ (II) in the snow crab over a 5 mo period, under environmental conditions similar to those encountered in the cold coastal waters this species inhabits. Retention efficiency and elimination rate were quantified with in vivo gamma counting, a technique allowing repeated monitoring of the activity of radioactive metal isotopes in the same individuals (Rouleau et al. 2000). The fine-scale tissue distribution of ${ }^{109} \mathrm{Cd}$ was determined by whole-body autoradiography (Ullberg et al. 1982). Data obtained from this laboratory study were used to model the trophic transfer of $\mathrm{Cd}$ in snow crab. Modeling results were then compared to $\mathrm{Cd}$ concentrations in snow crabs sampled in the Estuary and Gulf of St. Lawrence and in the Saguenay Fjord.

\section{MATERIALS AND METHODS}

Laboratory experiments. Mature female snow crabs were caught in October 1996 in the Estuary and Gulf of St. Lawrence and kept in large tanks supplied with aerated filtered flowing seawater under conditions of natural photoperiod and ambient water temperature. They were fed twice a week with shrimp and/or chopped capelin. This feeding frequency has proven successful in maintaining crabs in our laboratory for up to 2 yr.

Six of these crabs (50 to $80 \mathrm{~g}$, 50 to $60 \mathrm{~mm}$ shell width) were transferred to $60 \mathrm{l}$ aquaria provided with running seawater $\left(3\right.$ to $3.5^{\circ} \mathrm{C}$ ) 1 wk before the beginning of experiments in November 1996. Two crabs were housed in each aquarium. The day before the experiment started, supplemented fish food (Provencher et al. 1995) was spiked with ${ }^{109} \mathrm{Cd}(\mathrm{II})$ (New England Nuclear, $10.5 \mathrm{MBq} \mu \mathrm{mol}^{-1}, t_{1 / 2}=462.6 \mathrm{~d}$ ), thoroughly homogenised for $5 \mathrm{~min}$, and moulded in small balls weighing $0.3 \mathrm{~g}$. Spiked food was kept at $4^{\circ} \mathrm{C}$ overnight to allow for the binding of $\mathrm{Cd}$ to food components, such as proteins.

On Day 0, crabs were given 1 ball of ${ }^{109} \mathrm{Cd}$-spiked food each $(0.46 \mathrm{MBq}, 44 \mathrm{nmol})$ that they ate almost completely within $10 \mathrm{~min}$. Water in the aquarium was then changed immediately to avoid its contamination by radioactive $\mathrm{Cd}$ leaching from food particles. The radioactivity of the crabs was first monitored $1 \mathrm{~h}$ after feeding (see below). The animals were then fed with uncontaminated food as mentioned above from Day 3 until the end of the experiments. Weight of organisms during the experiment did not vary.

The rate of water renewal in the aquaria was kept high enough (1.5 to $2.01 \mathrm{~min}^{-1}$ ) to approximate an open system. Water samples $(3 \mathrm{ml})$ were collected at least twice a week throughout the experiments and their radioactivity was monitored for $10 \mathrm{~min}$ with an LKB Clinigamma counter. Radioactivity in all water samples was below the detection limit of $0.05 \mathrm{~Bq} \mathrm{ml}^{-1}$.

Whole-body ${ }^{109} \mathrm{Cd}$ activity was repeatedly monitored over $154 \mathrm{~d}$, using an in vivo gamma counting system consisting in a 3 inch (ca $76 \mathrm{~mm}$ ) NaI(Tl) gamma detector (Canberra-Packard, Meriden, CT) fitted into a $2 \mathrm{~cm}$ thick cylindrical $\mathrm{Pb}$ shield with a $0.6 \mathrm{~cm}$ thick copper-brass inside lining (Rouleau et al. 1998, Rouleau et al. 2000). The detector-shield assembly was fixed onto a specially designed stand and placed at $40 \pm 0.5 \mathrm{~mm}$ above the crabs, which were placed upside down, motionless, and positioned on a target drawn on plastic plate cut to the exact size of the base of the stand. The $88 \mathrm{keV} \gamma$-ray emission of ${ }^{109} \mathrm{Cd}$ was monitored for 1 to 3 min daily during the first $10 \mathrm{~d}$ and every 2 to $4 \mathrm{~d}$ thereafter. Crabs did not appear to be affected by the repeated manipulations needed for gamma counting, since they fed normally, behaved normally (no unusual activity that may have been indicative of stress), and their physical aspect did not change.

${ }^{109} \mathrm{Cd}$ activity was quantified with Genie-PC Gamma Analysis software (Canberra-Packard). After corrections for background and decay, activity data were standardised by expressing them as a percentage of the activity measured at the beginning of the experiment. The average statistical counting error was $1.3 \%$. The error due to variations in the positioning of animals under the detector, expressed as a coefficient of variation of 5 replicate measurements, was $2 \%$.

At the end of the experiments, all animals were sacrificed and dissected. The hepatopancreas was collected, weighed, uniformly spread over the surface of a 
$60 \mathrm{~mm}$ Petri dish, and its radioactivity measured. Legs were separated from the body and radioactivity measured as above. Radioactivity of the body, of which the size and shape was similar to that of the Petri dish used, was counted and this value added to the value obtained from the legs. Data obtained were used to calculate the percentage of the Cd body burden contained in the hepatopancreas and in the rest of the body (body + legs). The concentration index, $I_{\mathrm{C}}$, was then calculated as:

$I_{\mathrm{C}}=\frac{\% \text { of body burden }\left({ }^{109} \mathrm{Cd} \text { activity in tissue } /{ }^{109} \mathrm{Cd} \text { activity in whole body } \times 100\right)}{\% \text { of body weight }(\mathrm{g} \text { tissue } / \mathrm{g} \text { whole body } \times 100)}$

which is equivalent to the ratio of the concentration of ${ }^{109} \mathrm{Cd}$ in the tissue over the whole-body averaged:

$$
I_{\mathrm{C}}=\frac{\left[{ }^{109} \mathrm{Cd}\right] \text { in tissue }}{\left[{ }^{109} \mathrm{Cd}\right] \text { in whole body }}
$$

Values of $I_{\mathrm{C}}>1$ indicate that a tissue is enriched in ${ }^{109} \mathrm{Cd}$ compared to the average whole-body metal concentration.

Additional snow crabs were used for whole-body autoradiography (Ullberg et al. 1982). Four snow crabs were fed as mentioned above and 2 of them were sampled at each of Days 3 and 14. Immediately after removal from their aquaria, the animals were embedded in a carboxymethylcellulose gel and quickly frozen in a slurry of hexane and dry ice. Resulting blocks were sectioned on tape (50 $\mu \mathrm{m}$ thick sections) at $-20^{\circ} \mathrm{C}$ with a specially designed cryomicrotome (Jung Cryomacrocut, Leica). Tissue sections were then freezedried and applied to an X-ray film $\left({ }^{3} \mathrm{H}\right.$-Hyperfilm, Amersham) for $40 \mathrm{~d}$, at $-20^{\circ} \mathrm{C}$.

Field measurements. Mature adult female ( $\mathrm{n}=32$, body weight $=82 \pm 13 \mathrm{~g}$, carapace width $=62 \pm 3 \mathrm{~mm}$ ) and male $(\mathrm{n}=60$, body weight $=580 \pm 169 \mathrm{~g}$, carapace width $=112 \pm 10 \mathrm{~mm}$ ) snow crabs were caught in 1998 and 1999 in the Saguenay Fjord, the St. Lawrence Estuary, and the northeastern part of the Gulf of St. Lawrence (Fig. 1). The size difference reflects the important sexual dysmorphism in this species. The organisms were immediately measured, weighed, and stored at $-20^{\circ} \mathrm{C}$ in clean plastic bags. In the laboratory, muscle and hepatopancreas were collected, homogenized, freeze-dried, and digested in a microwave oven with nitric acid (Nakashima et al. 1988). Cd concentration in the tissues was determined by atomic absorption spectroscopy using a graphite furnace. The detection limit, estimated as 3 times the standard deviation of measures made on analytical blanks, was $0.02 \mathrm{nmolCd}$ $\mathrm{g}^{-1}$ wet wt. Biological reference material DORM-1 from

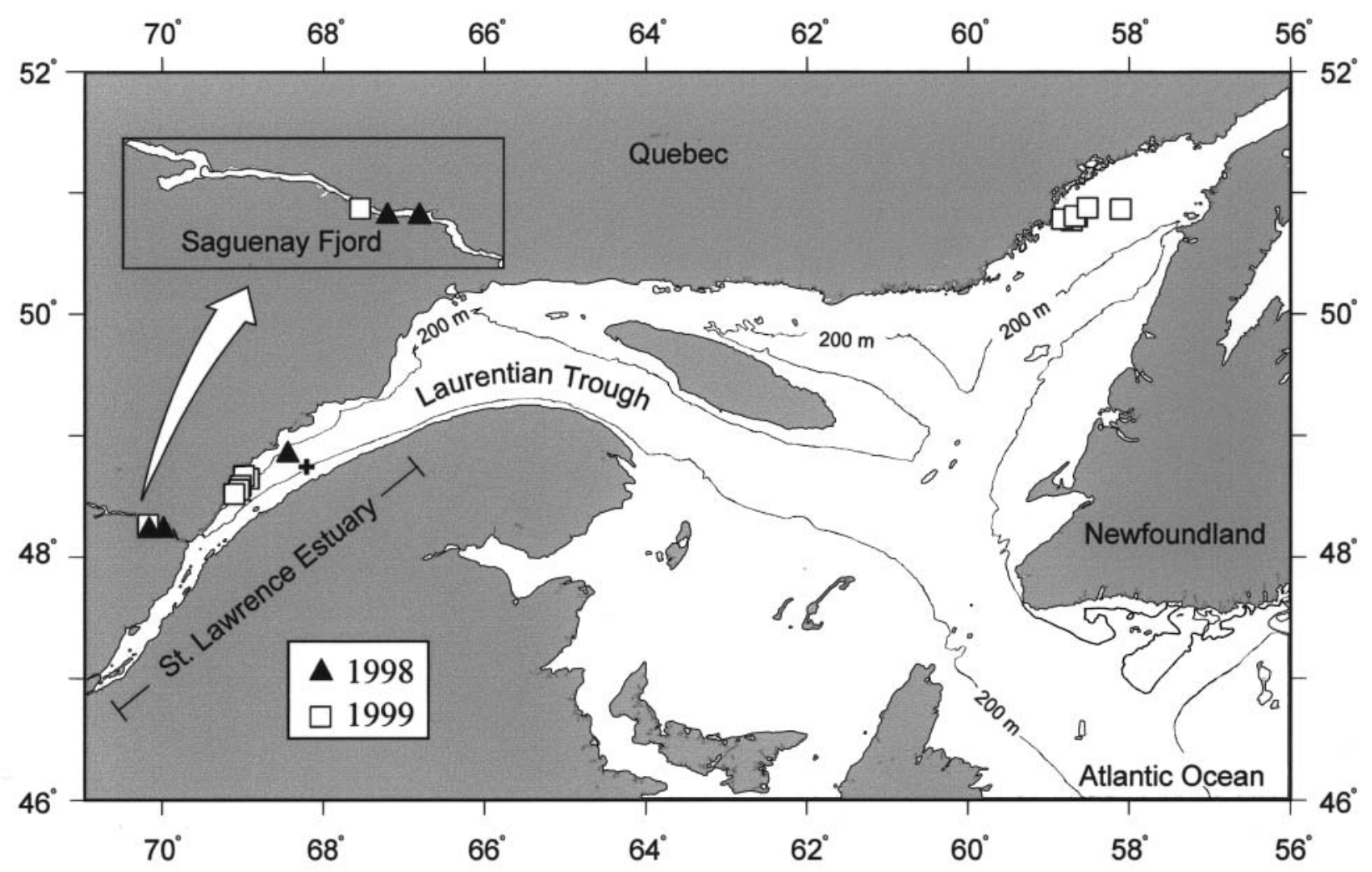

Fig. 1. Location of sites of snow crab captures for the field survey. $\mathbf{+}$ indicates the site of capture of crabs used in the laboratory experiment 
the National Research Council of Canada having a certified Cd concentration of $0.77 \pm 0.11 \mathrm{nmol} \mathrm{g}^{-1}$ dry wt was used to assess of the quality of our analyses. The precision was $6 \%$ and analytical accuracy was always within prescribed limits $(\mathrm{n}=15)$.

$\mathrm{Cd}$ concentrations were compared according to sampling location and sex. Values of standard skewness and standard kurtosis were outside the prescribed range for some of the groups. Also, variance significantly differed from one group to another, even for log-transformed data. Thus, we use the Kruskal-Wallis test to compare median Cd levels between sexes for a given sampling site and between sampling sites.

\section{RESULTS}

\section{Pharmacokinetics}

The temporal change of ${ }^{109} \mathrm{Cd}$ activity in the snow crabs is illustrated in Fig. 2. Activity sharply decreased at Days 2 to 3 as non-retained Cd was eliminated with faeces. After defecation, ${ }^{109} \mathrm{Cd}$ elimination proceeded at a slower rate. Linear regression analysis of ${ }^{109} \mathrm{Cd}$ activity, $\mathrm{Cd}_{t}$, plotted as a function of time $(t)$ was first used to calculated the retention efficiency, $\mathrm{RE}_{0}$ (i.e. the percentage of the dose ingested that was retained within the body after the elimination of non-retained Cd with faeces; $0 \leq \mathrm{RE}_{0} \leq 100 \%$ ), and the first order elimination rate constant, $\beta$, using:

$$
\operatorname{lnCd} d_{t}=\operatorname{lnRE} E_{0}-\beta t
$$

However, elimination kinetic was biexponential for Crabs 2, 3, and 6; activity decreased faster in the first 20 to $25 \mathrm{~d}$ than during the interval between Days 25 and 154. In these cases, non-linear regression analysis was used with the following biexponential equation:

$$
\mathrm{Cd}_{t}=\mathrm{A}_{0} \mathrm{e}^{-\alpha t}+\mathrm{B}_{0} \mathrm{e}^{-\beta t}
$$

where $\alpha$ and $\beta$ are first order rate constants characterising the fast and slow eliminating pools respectively, whereas $A_{0}$ and $B_{0}$ are the initial amounts of radioactivity in each pool $\left(\mathrm{A}_{0}+\mathrm{B}_{0}=\mathrm{RE}_{0}\right)$.

On average, Crabs 2,3, and 6 retained $75 \%$ of the $\mathrm{Cd}$ dose ingested (Table 1). About half of the dose retained was eliminated rapidly within 8 to $20 \mathrm{~d}$, as calculated from the value of $\alpha$ (Table 1 ). The propor-
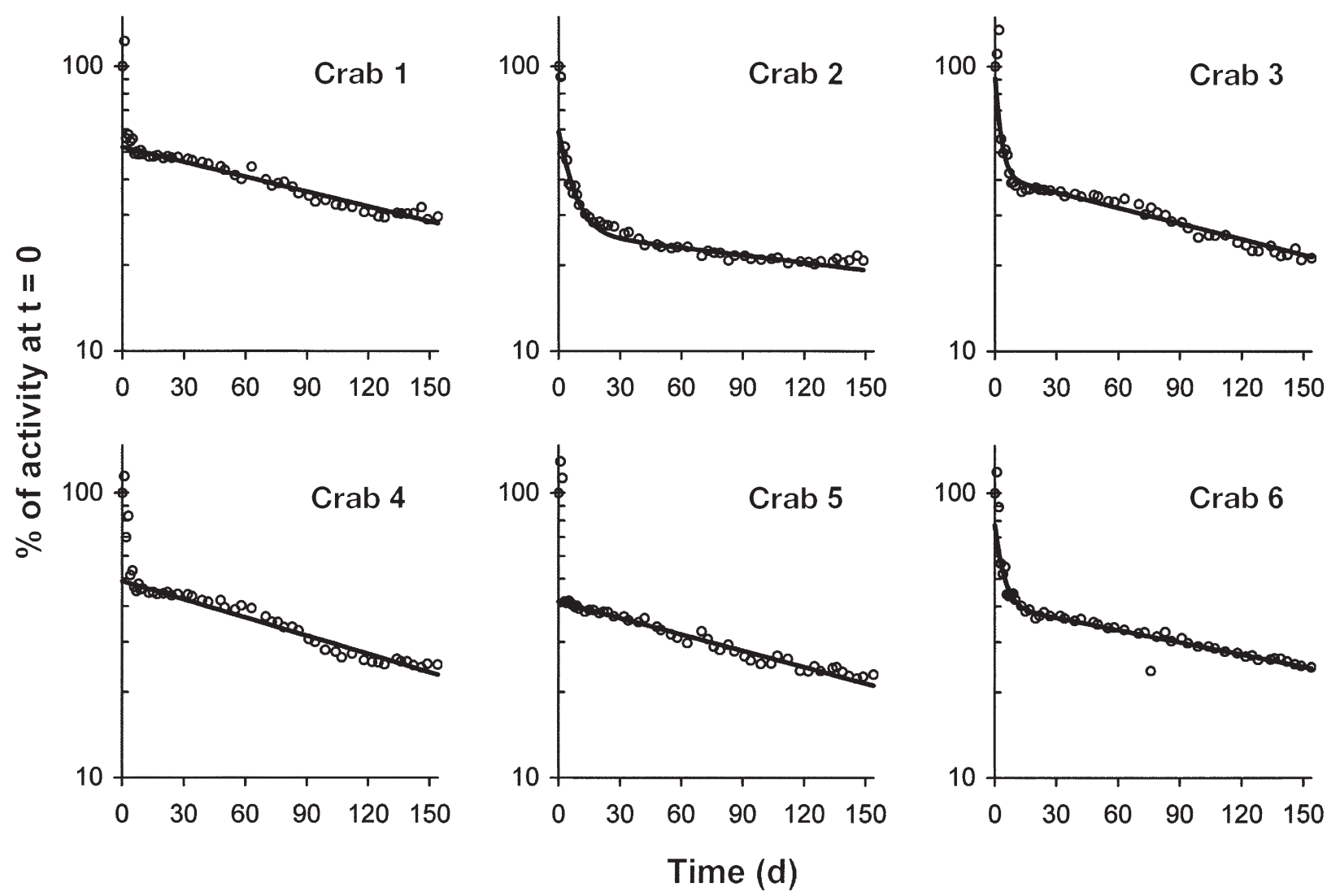

Fig. 2. Chionoecetes opilio. Change of ${ }^{109} \mathrm{Cd}$ activity measured over $154 \mathrm{~d}$ in female crabs. Data are standardised as a percentage of the radioactivity measured immediately after feeding 
Table 1. Chionoecetes opilio. Kinetic parameters of dietary ${ }^{109} \mathrm{Cd}(\mathrm{II})$. Values $( \pm \mathrm{SE})$ of $\mathrm{A}_{0}, \mathrm{~B}_{0}, \mathrm{RE}_{0}$, and rate constants $\alpha$ and $\beta$ were calculated from experimental data, excluding data from Days 0 to 3 . Time to eliminate $95 \%$ of pool $\mathrm{A}$ and $\mathrm{B}$, $t_{0.95 \alpha}$ and $t_{0.95 \beta}$, and biological half-life of pool $\mathrm{B}, t_{0.5 \beta}$, were calculated with $2.996 /$ rate constant and $0.693 /$ rate constant respectively

\begin{tabular}{|c|c|c|c|c|c|c|c|c|c|}
\hline & $\begin{array}{c}\mathrm{A}_{0} \\
(\%)\end{array}$ & $\begin{array}{c}\mathrm{B}_{0} \\
(\%)\end{array}$ & $\begin{array}{l}\mathrm{RE}_{0} \\
(\%)\end{array}$ & $\begin{array}{c}\alpha \\
\left(\mathrm{d}^{-1}\right)\end{array}$ & $\begin{array}{l}t_{0.95 \alpha} \\
\text { (d) }\end{array}$ & $\begin{array}{c}\beta \\
\left(\mathrm{d}^{-1}\right)\end{array}$ & $\begin{array}{l}t_{0.5 \beta} \\
\text { (d) }\end{array}$ & $\begin{array}{c}t_{0.95 \beta} \\
\text { (d) }\end{array}$ & $r^{2}$ \\
\hline Crab 1 & - & - & $52.1 \pm 0.4$ & - & - & $0.0040 \pm 0.0001$ & 173 & 750 & 0.97 \\
\hline Crab 2 & $33.3 \pm 1.8$ & $26.4 \pm 0.7$ & $59.7 \pm 2.5$ & $0.148 \pm 0.014$ & 20 & $0.0020 \pm 0.0003$ & 346 & 1500 & 0.97 \\
\hline Crab 3 & $50.2 \pm 13.0$ & $40.9 \pm 0.7$ & $90.7 \pm 13.7$ & $0.379 \pm 0.070$ & 8 & $0.0042 \pm 0.0002$ & 165 & 710 & 0.96 \\
\hline Crab 4 & - & - & $49.2 \pm 0.5$ & - & - & $0.0049 \pm 0.0001$ & 141 & 610 & 0.97 \\
\hline Crab 5 & - & - & $41.5 \pm 0.3$ & - & - & $0.0044 \pm 0.0001$ & 158 & 680 & 0.98 \\
\hline Crab 6 & $37.4 \pm 6.6$ & $40.3 \pm 0.7$ & $77.7 \pm 7.3$ & $0.259 \pm 0.044$ & 12 & $0.0033 \pm 0.0001$ & 210 & 910 & 0.96 \\
\hline
\end{tabular}

tion of the initial metal dose then retained in the slow pool, $\mathrm{B}_{0}$, was similar to the values of $\mathrm{RE}_{0}$ found for the three other crabs (26 to $52 \%$ ). Biological half-life values $\left(t_{0.5 \beta}\right)$ of $\mathrm{Cd}$ varied from 141 to $346 \mathrm{~d}$.

\section{Tissue distribution.}

Whole-body autoradiograms are shown in Fig. 3. To compare the radiolabelling of the various tissues semiquantitatively, the autoradiograms were digitised as black and white images with 256 values of grey, and average grey value (AGV) of the various areas was determined (Table 2).

Three days after the administration of ${ }^{109} \mathrm{Cd}$ with food, most of the radioactive metal was located in the hepatopancreas (Fig. 3). The AGV of 247 (Table 2) corresponds to a complete saturation of the X-ray film. The very high level of radioactivity in the hepatopancreas resulted in some fogging of the X-ray film that renders difficult the evaluation of the relative labelling of other tissues. This is well illustrated by the fact that the AGV for the respiratory chambers, which contain only water and should not be labelled, was higher than that of background. Nevertheless, it can be seen that some of the radiolabel has already been transferred toward the other tissues, e.g. the antennal glands, the gills, and the hypodermis. However, areas corresponding to the foregut, muscle, and gonads had AGV values similar to those of tissues mentioned above (Table 2), although there was no evident labelling visible in the autoradiogram (Fig. 3). There was no labelling noticeable for the spermathecae and the exoskeleton.

The distribution picture is clearer in the autoradiograms obtained $14 \mathrm{~d}$ after feeding. Fogging of the film was less important and the AGV for the respiratory chambers was similar to background. This allows a better discrimination of the radioactivity level in tissues other than gut and hepatopancreas, for which the concentration of ${ }^{109} \mathrm{Cd}$ decreased in the order antennal glands $\geq$ hemolymph $>$ gonads $>$ gills $\approx$ hypodermis $\approx$ muscle $>$ eye. The spermathecae and the exoskeleton were not noticeably labelled. The $40 \mathrm{~d}$ exposure of tissue sections to film still resulted in a saturation of the film in areas corresponding to hepatopancreas. Such saturation was also seen for the foregut, midgut, and hindgut.

Table 2. Chionoecetes opilio. Average grey value $(\mathrm{AGV}) \pm \mathrm{SD}(1=$ black, $256=$ white $)$ and tissue/background ratio for various areas of the digitised whole-body autoradiograms shown in Fig. 3. Values within brackets are the number of pixels quantified

\begin{tabular}{|c|c|c|c|c|c|}
\hline & $\begin{aligned} t= & 3 \mathrm{~d} \\
& \mathrm{AGV}\end{aligned}$ & Tissue/background & & $\begin{aligned} t= & 14 \mathrm{~d}- \\
& \mathrm{AGV}\end{aligned}$ & Tissue/background \\
\hline Background & $34 \pm 17$ [139700] & - & Background & $2 \pm 4 \quad[47500]$ & - \\
\hline Respiratory chambers & $60 \pm 8 \quad[2840]$ & 1.8 & Respiratory chambers & $2 \pm 3 \quad[1790]$ & 1 \\
\hline Foregut & $94 \pm 13[4350]$ & 2.8 & Foregut & $245 \pm 14[7050]$ & 122 \\
\hline Hepatopancreas & $247 \pm 3 \quad[33830]$ & 7.3 & Hepatopancreas & $246 \pm 13$ [18100] & 123 \\
\hline Gonads & $90 \pm 6 \quad[5970]$ & 2.6 & Gonads & $61 \pm 19$ [8790] & 30 \\
\hline Gills & $66 \pm 12[11070]$ & 1.9 & Gills & $34 \pm 11$ [2960] & 17 \\
\hline Hypodermis & $69 \pm 11[2220]$ & 2.0 & Hypodermis & $24 \pm 8$ & 12 \\
\hline Antennal gland & $100 \pm 12[2120]$ & 2.9 & Antennal gland & $119 \pm 17[1210]$ & 59 \\
\hline Muscle & $82 \pm 10[3760]$ & 2.4 & Muscle & $21 \pm 9$ & 10 \\
\hline Hemolymph & - & - & Hemolymph & $91 \pm 20[380]$ & 45 \\
\hline Eye & - & - & Eye & $13 \pm 7 \quad[2230]$ & 6 \\
\hline
\end{tabular}



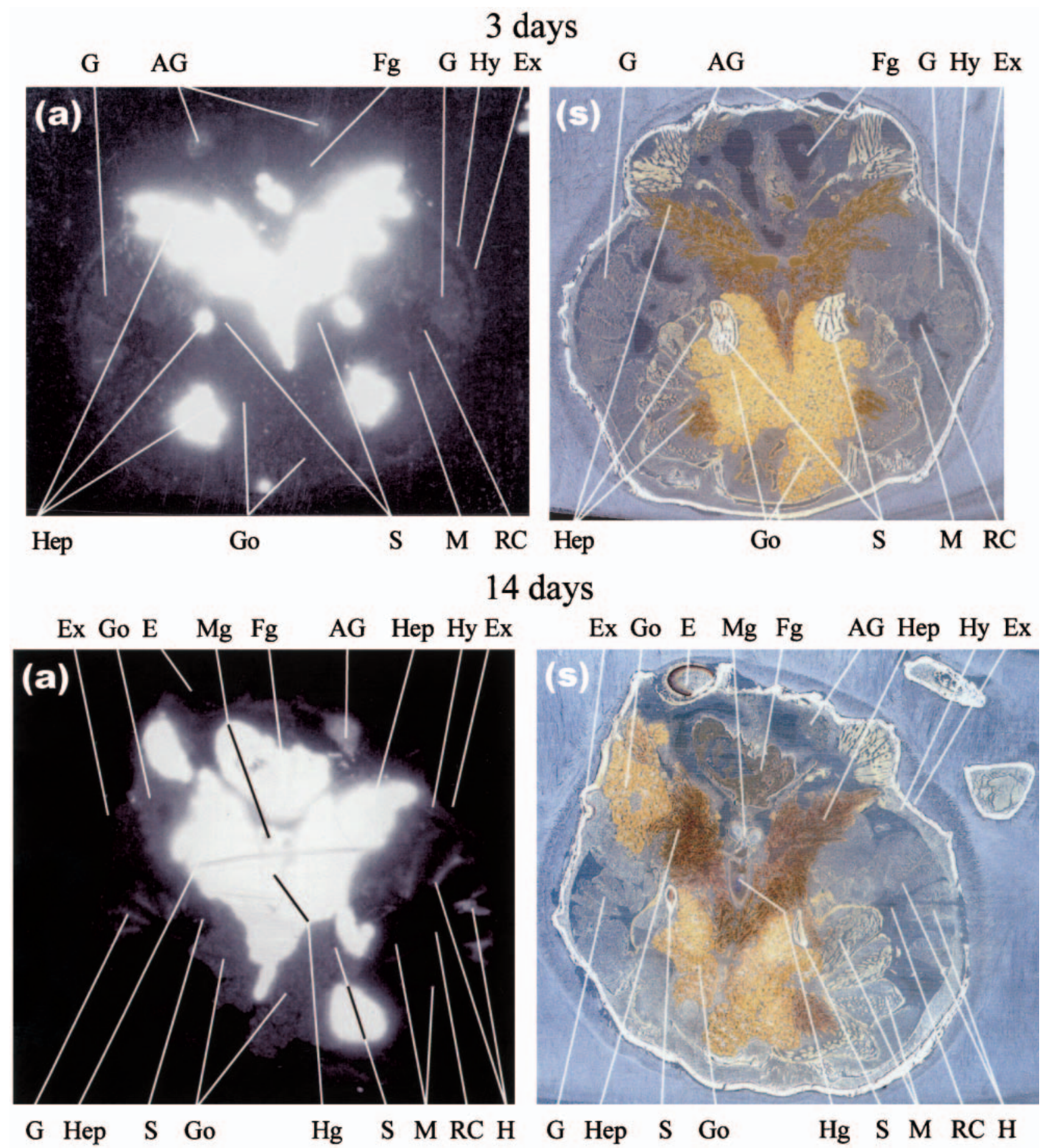

$\mathrm{Hg}$

S M RC H

G Hep S Go

$\mathrm{Hg} \quad \mathrm{S}$ M RC H

Fig. 3. Chionoecetes opilio. Whole-body autoradiograms from female snow crab sampled 3 and $14 \mathrm{~d}$ after feeding with a single dietary dose of ${ }^{109} \mathrm{Cd}$. (a) Autoradiogram, (s) corresponding tissue section. White areas correspond to high concentrations of the radiolabel. Exposure time: $40 \mathrm{~d}$. $\mathrm{AG}=$ antennal gland, $\mathrm{E}=$ eye, $\mathrm{Ex}=$ exoskeleton, $\mathrm{Fg}=$ foregut, $\mathrm{G}=$ gills, Go $=$ gonads, $\mathrm{H}=$ hemolymph, $\mathrm{Hep}=$ hepatopancreas, $\mathrm{Hg}=$ hindgut, $\mathrm{Hy}=$ hypodermis, $\mathrm{Mg}=$ midgut, $\mathrm{M}=$ muscle, $\mathrm{RC}=$ respiratory chamber, $\mathrm{S}=$ spermathecae

To have a better view of the relative labelling of gut and hepatopancreatic tissues, some autoradiograms were applied again to film for $1 \mathrm{~d}$ only (Fig. 4). This allows visual confirmation that ${ }^{109} \mathrm{Cd}$ concentrations were the highest in hepatopancreatic tissues at Day 14. The labelling of all parts of the gut was less intense. It is noteworthy that the labelling of hepatopancreatic diverticula wall is higher than that of the lumen. 

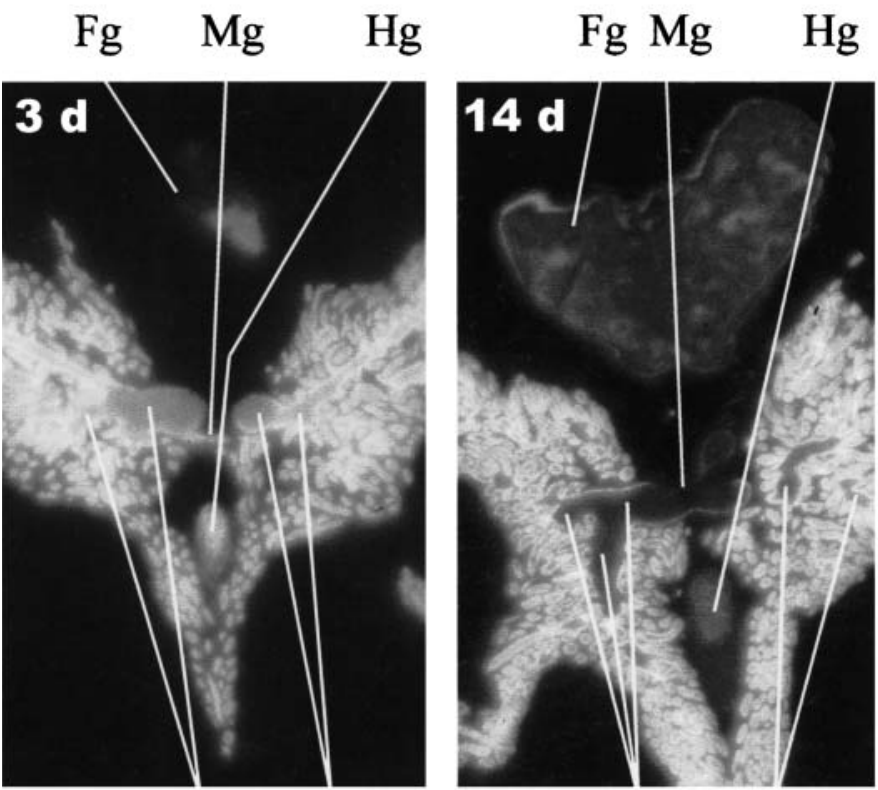

\section{Lumen of hepatopancreas diverticulae}

Fig. 4. Chionoecetes opilio. Detail of whole-body autoradiograms from female snow crab sampled 3 and $14 \mathrm{~d}$ after feeding with a single dietary dose of ${ }^{109} \mathrm{Cd}$. Exposure time: $1 \mathrm{~d}$. $\mathrm{Fg}=$ foregut, $\mathrm{Hg}=$ hindgut, $\mathrm{Mg}=$ midgut

For crabs sampled at Day 3, the labelling of hindgut lumen and hepatopancreatic diverticula lumen relative to hepatopancreatic tissues was higher than at Day 14.

At Day 154 (Fig. 5), the hepatopancreas contained almost $70 \%$ of the body burden of ${ }^{109} \mathrm{Cd}$, whereas the rest of body accounted for the remaining $30 \%$. Because of its small size compared to the rest of the body, average value of $I_{\mathrm{C}}$ for hepatopancreas was an order of magnitude higher $\left(I_{\mathrm{C}}=7.5 \pm 0.8\right.$ and $0.36 \pm 0.07$, respectively). This distribution is similar to that observed in autoradiograms at Day 14, indicating that the distribution of dietary ${ }^{109} \mathrm{Cd}$ within the body of the snow crabs rapidly reached equilibrium.

\section{Cd in snow crabs from the St. Lawrence and the Saguenay fjord}

Field data are shown in Fig. 6. Similar cadmium concentrations were found in the hepatopancreas of snow crabs of both sexes sampled in the Estuary and Gulf of St. Lawrence (range 3.5 to $32.9 \mathrm{nmolCd} \mathrm{g}^{-1}$ wet wt). Cadmium levels in the hepatopancreas of male crabs from the Saguenay (range $6.0-88.2 \mathrm{nmolCd} \mathrm{g}^{-1}$ wet wt) were significantly higher compared to the other groups (Kruskal-Wallis test, $\mathrm{p}<10^{-5}$ ). In general, Cd concen-
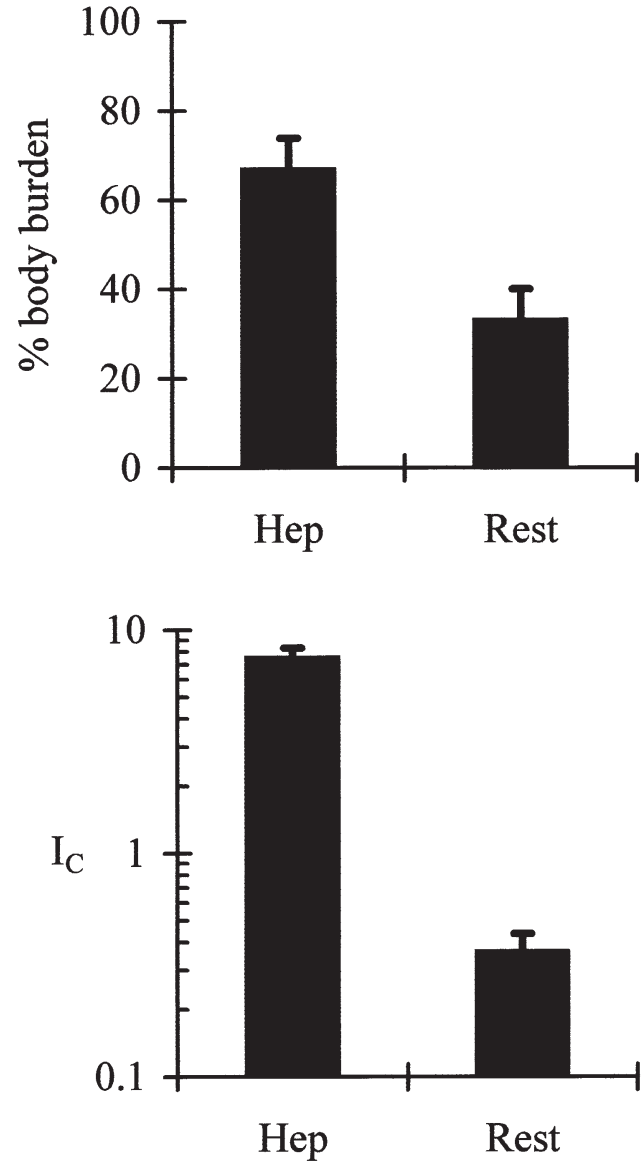

Fig. 5. Chionoecetes opilio. Percentage of ${ }^{109} \mathrm{Cd}$ body burden and concentration index, $I_{\mathrm{C}}$ of hepatopancreas and rest of body of snow crabs $(n=6)$ dissected $154 \mathrm{~d}$ after feeding with ${ }^{109} \mathrm{Cd}$-contaminated food. Values are means $\pm \mathrm{SD}$. Hep $=$ hepatopancreas, Rest $=$ rest of body

trations measured in the muscle were an order of magnitude lower compared to the hepatopancreas. However, Cd levels measured in the muscle of female crabs from the Gulf of St. Lawrence (range 0.5 to $5.4 \mathrm{nmolCd}$ $\mathrm{g}^{-1}$ wetwt) were significantly higher than for other groups (range 0.1 to $1.9 \mathrm{nmol} \mathrm{Cd} \mathrm{g}^{-1}$ wet wt; KruskalWallis test, $\mathrm{p}<0.01$ ).

\section{DISCUSSION}

\section{Pharmacokinetics and distribution}

Autoradiograms give some clues about the processing of dietary ${ }^{109} \mathrm{Cd}$ in the snow crab. The low labelling of foregut in autoradiograms taken at Day 3 shows that the radiolabel was efficiently transferred to the hepatopancreas. The relatively high labelling of hindgut and hepatopancreatic diverticula lumen may be related to the presence of non-assimilated ${ }^{109} \mathrm{Cd}$. The 


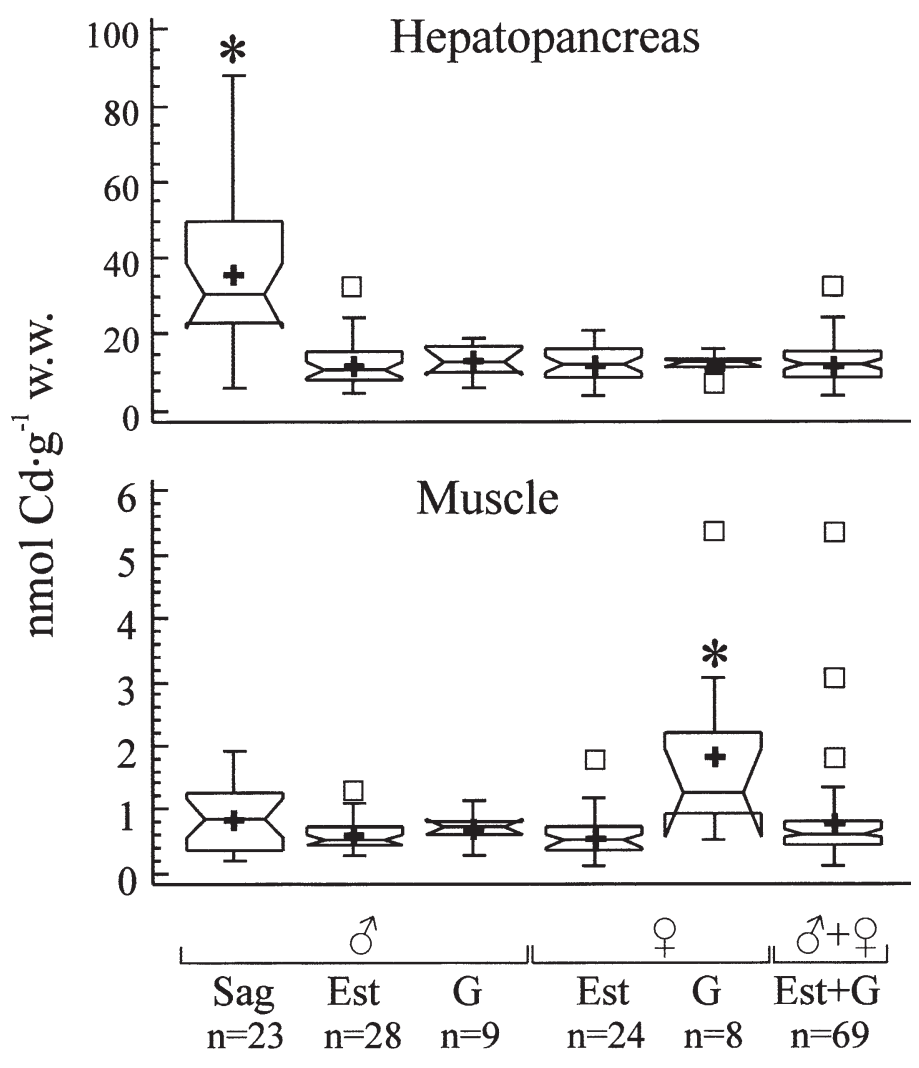

Fig. 6. Chionoecetes opilio. Box-and-Whisker plot of Cd concentration in the hepatopancreas and muscle of snow crabs sampled in the Estuary and Gulf of St. Lawrence and in the Saguenay Fjord. Horizontal bar in box is median concentration, $\mathbf{+}$ : average concentration, $\square$ : outlier data, and $*$ : significantly higher Cd levels for a given group (Kruskal-Wallis test, see text)

labelling of all parts of the gut, including the foregut, at Day 14 indicates that small quantities of the radioactive metal initially stored in the hepatopancreatic tissues were transferred back into the luminal space, transported to the foregut and midgut with the digestive juices (Dall \& Moriarty 1983), and subsequently eliminated via the hindgut. This distribution picture is likely typical of the slow long-term elimination of assimilated $\mathrm{Cd}$.

The mechanism underlying the bi-exponential elimination kinetics observed for 3 of the snow crabs is not clear. It might be due to interindividual variations of the rate of the initial processing of contaminated food, which would have been slower in these cases. The occurrence of two kinetically distinct metal pools may have an impact on the choice of a long-term kinetic model of the fate of dietary $\mathrm{Cd}$ in the snow crab, e.g. choosing a 1- or a 2-compartment model. Although the proportion of the metal dose retained in the fast pool $\mathrm{A}$ was similar to that of the slow pool B, it is noteworthy that the former was eliminated some 70 times faster, as shown by the values of $t_{0.95 \alpha}$ and $t_{0.95 \beta}$ (Table 1 ). It is thus reasonable to expect that the long-term kinetics of

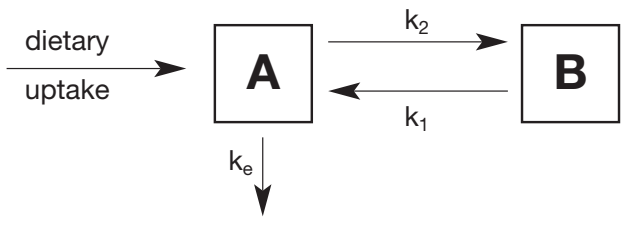

Cd in the snow crab can be well described by the slow compartment only (Trudel \& Rasmussen 1997). As a precaution, we used the data from Crabs 2, 3, and 6 to compute the long-term kinetics of dietary $\mathrm{Cd}$ with the classical 2-compartment model shown below, in which uptake and elimination (characterised by the rate constant $\mathrm{k}_{\mathrm{e}}$ ) take place in the same compartment, whereas exchange between compartments are characterised by rate constants $\mathrm{k}_{1}$ and $\mathrm{k}_{2}$.

Results suggest that Pool A is indeed negligible, since it would account for $\leq 5 \%$ of the total Cd burden. Thus, for Crabs 2, 3, and 6, only the slow pool B will be considered in further discussion, e.g. the value of $\mathrm{RE}_{0}$ for these individuals will be considered equal to the value of $\mathrm{B}_{0}$ only (Table 1 ).

Compared to Ag(I) and inorganic Hg(II) (Rouleau et al. 1999 , 2000), values of $\mathrm{RE}_{0}$ observed for dietary Cd(II) are 2 times lower, whereas elimination rate is slower than for inorganic $\mathrm{Hg}\left(\beta\right.$ range $=0.011$ to $0.022 \mathrm{~d}^{-1}$ ) and faster than for $\operatorname{Ag}\left(\beta<0.0007 \mathrm{~d}^{-1}\right)$. Like Ag, dietary Cd was rapidly distributed to all internal tissues. Both autoradiographic and quantitative data correspond to the general distribution observed for wild crabs, with Cd concentrations in muscle and/or gonads that are lower compared to hepatopancreas (Davies et al. 1981, Kannan et al. 1995, this work). An interesting observation is the labelling of the antennal glands (Fig. 3), which was not observed for the other metals and organometals we studied previously (Rouleau et al. 1999, 2000). Antennal glands are the main excretory organs of decapod crustaceans (McLaughlin 1983). Their role is similar to that of the kidney in fish and mammals, which is a known target organ for Cd (Tjälve et al. 1986, Beresford et al. 1999). The autoradiographic evidence presented here suggest that antennal glands may be implicated in the storage, sequestration, or excretion of $\mathrm{Cd}$. They might also be a specific target for $\mathrm{Cd}$ toxicity. Additional research work will be necessary to further investigate the possible chronic effects of $\mathrm{Cd}$ on the excretory processes of the snow crab and other decapod crustaceans.

\section{Field data}

Cd concentrations measured in the hepatopancreas and muscle of the snow crab (Fig. 6) are similar to those 
laboratory data and estimate of $\mathrm{Cd}$ levels in food, the agreement between modelled and field Cd concentrations is quite good. Predicted average concentrations were only 1.6 to 1.8 times higher than field data, whereas predicted and field range (expressed as: $\log _{10}$ $[\mathrm{Cd}]_{\max }-\log _{10}[\mathrm{Cd}]_{\min }$ ) differed by no more than $0.3 \log$ unit.

In order to refine the model, more data will be needed about $\mathrm{Cd}$ levels in snow crab prey. Another factor that will need to be considered is the effect of the biological incorporation of $\mathrm{Cd}$ on retention efficiency. Wallace et al. (1998) showed that the bioavailability of the cytosolic fraction of $\mathrm{Cd}$ in the oligochaete Limnodrilus hoffmeisteri was much higher than that of $\mathrm{Cd}$ in metal-rich granules, and that the absorption of $\mathrm{Cd}$ by the grass shrimp Paleomontes pugio fed with these worms was directly related to the proportion of bioavailable $\mathrm{Cd}$ (e.g. the cytosolic fraction) in the latter. The food to which we added ${ }^{109} \mathrm{Cd}$ for our laboratory experiment contained $40 \%$ water and, on a dry weight basis, $47 \%$ protein, $24 \%$ carbohydrates, and $8 \%$ lipid. Proteins, to which bioavailable $\mathrm{Cd}$ atoms are bound in the cytosolic fraction of natural prey, were in large excess relative to the ${ }^{109} \mathrm{Cd}$ added. It is thus reasonable to assume that ${ }^{109} \mathrm{Cd}$ in the food given to snow crabs was mostly bound to proteins and had a behaviour similar to that of the metal contained within the cytosolic fraction of naturally contaminated living prey. Thus, the use of spiked food to feed the snow crabs, instead of live prey that had previously accumulated $\mathrm{Cd}$, though technically convenient, may have resulted in an overestimation of $\mathrm{RE}_{0}$. This would explain the somewhat higher predicted values of $C_{\mathrm{P}}$ compared to field data.

\section{CONCLUSION}

Although direct uptake of Cd by snow crab from either the sediment or water cannot be excluded at present, the similarity between our laboratory-based predictions and field data strongly suggests that trophic uptake is an important accumulation route of $\mathrm{Cd}$ in snow crab living in the St. Lawrence. Based on experimental data, the quantitative relationships between exposure to $\mathrm{Cd}$ in food and equilibrium $\mathrm{Cd}$ levels in snow crab tissues (Eq. 7) are:

$$
\begin{aligned}
& {[\mathrm{Cd}]_{\text {hepatopancreas }}=C_{\mathrm{F}} 2.9 \text { (range } 1.6 \text { to } 5.3 \text { ) }} \\
& {[\mathrm{Cd}]_{\text {muscle }}=C_{\mathrm{F}} 0.14 \text { (range } 0.07 \text { to } 0.23 \text { ) }}
\end{aligned}
$$

Improvement of these relationships would eventually be possible through a better knowledge of the Cd concentrations in the prey organisms of the snow crab.
Acknowledgements. This work was supported by the Toxic Chemicals Program of the Canadian Department of Fisheries and Oceans and by the Swedish Foundation for Strategic Environmental Research. The authors gratefully acknowledge the technical assistance of Luc Beaudin, Julie Bolduc, Agneta Boström, and Paul Robichaud.

\section{LITERATURE CITED}

Alunno-Bruscia M, Sainte-Marie B (1998) Abdomen allometry, ovary development, and growth of female snow crab, Chionoecetes opilio (Brachyura, Majidae), in the northwestern Gulf of St. Lawrence. Can J Fish Aquat Sci 55: 459-477

Bailey RFJ, Elner RW (1989) In: Caddy JF (ed) Marine invertebrates fisheries: their assessment and management. John Wiley and Sons, New York, p 261-280

Beresford NA, Mayes RW, Crout NMJ, MacEachern PJ, Dodd BA, Barnett CL, Lamb CS (1999) Transfer of cadmium and mercury to sheep tissues. Environ Sci Technol 33:2395-2402

Bjerregaard P (1985) Effect of selenium on cadmium uptake in the shore crab Carcinus maenas (L.). Aquat Toxicol 7 : 177-189

Bjerregaard P (1990) Influence of physiological condition on cadmium transport from haemolymph to hepatopancreas in Carcinus maenas. Mar Biol 106:199-209

Bjerregaard P (1991) Relationship between physiological condition and cadmium accumulation in Carcinus maenas (L.). Comp Biochem Physiol 99A:75-83

Bjerregaard P, Depledge MH (1994) Cadmium accumulation in Littorina littorea, Mytilus edulis and Carcinus maenas: the influence of salinity and calcium ion concentrations. Mar Biol 119:385-395

Brêthes JC, Parent B, Pellerin J (1994) Enzymatic activity as an index of trophic resource utilization by the snow crab Chionoecetes opilio (O. Fabricius) J Crustac Biol 14: 220-225

Dall W, Moriarty DJW (1983) Functional aspects of nutrition and digestion. In: Mantel LH (ed) The biology of crustacea. Vol. 5. Internal anatomy and physiological regulation. Academic Press, p 215-261

Davies IM, Topping G, Graham WC, Falconer CR, McIntosh AD, Saward D (1981) Field and experimental studies on cadmium in the edible crab Cancer pagurus. Mar Biol 64:291-297

Everaarts JM, Nieuwenhuize J (1995) Heavy metals in surface sediment and epibenthic macroinvertebrates from the coastal zone and continental slope of Kenya. Mar Pollut Bull 31:281-289

Fowler SW (1982) Biological transfer and transport processes. In: Kullenberg G (ed) Pollutant transfer and transport in the sea. Vol. 2. CRC Press, Boca Raton, FL, p 1-65

Gobeil C, Macdonald RW, Sundby B (1997) Diagenetic separation of cadmium and manganese in suboxic continental margin sediments. Geochim Cosmochim Acta 61:4647-4654

Jennings JR, Rainbow PS (1979) Studies on the uptake of cadmium by the crab Carcinus maenas in the laboratory. I. Accumulation from seawater and a food source. Mar Biol 50:131-139

Kannan K, Yasunaga Y, Iwata $\mathrm{H}$, Ichihashi $\mathrm{H}$, Tanabe $\mathrm{S}$, Tatsukawa R (1995) Concentrations of heavy metals, organochlorines, and organotins in horseshoe crab, Tachypleus tridentatus, from Japanese coastal waters. Arch Environ Contam Toxicol 28:40-47

Landrum PF, Lee H II, Lydy MJ (1992) Toxicokinetics in aquatic 
systems: model comparison and use in hazard assessment. Environ Toxicol Chem 11:1709-1725

Lee BG, Griscom SB, Lee JS, Choi HJ, Koh CH, Luoma SN, Fisher NS (2000a) Influences of dietary uptake and reactive sulfides on metal bioavailability from aquatic sediments. Science 287:282-284

Lee BG, Lee JS, Luoma SN, Choi HJ, Koh CH (2000b) Influence of acid volatile sulfide and metal concentrations on metal bioavailability to marine invertebrates in contaminated sediments. Environ Sci Technol 34:4517-4523

Lee JS, Lee BG, Luoma SN, Choi HJ, Koh CH, Brown CL (2000c) Influence of acid volatile sulfides and metal concentrations on metal partitioning in contaminated sediments. Environ Sci Technol 34:4511-4516

Lovrich GA, Sainte-Marie B (1997). Cannibalism in the snow crab Chionoecetes opilio (O. Fabricius) (Brachyura: Majidae), and its potential importance to recruitment. J Exp Mar Biol Ecol 211:225-245

Martin DJ, Rainbow PS (1998) The kinetics of zinc and cadmium in the haemolymph of the shore crab Carcinus maenas (L.). Aquat Toxicol 40:203-231

McLaughlin PA (1983) Internal anatomy. In: Mantel LH (ed) The biology of crustacea. Vol. 5. Internal anatomy and physiological regulation. Academic Press, p 1-53

Nakashima S, Sturgeon RE, Willie SN, Berman S (1988) Acid digestion of marine samples for trace element analysis using microwave heating. Analyst 113:159-163

Ozretic B, Krajnovic-Ozretic M, Santin J, Medjugorac B, Kras M (1990) As, Cd, Pb, and $\mathrm{Hg}$ in benthic animals from the Kvarner-Rijeka region, Yugoslavia. Mar Pollut Bull 21:595-598

Pelletier É, Canuel G (1988) Trace metals in surface sediments of the Saguenay fjord, Canada. Mar Pollut Bull 19:336-338

Provencher L, Bryl P, Gendron A, Roy F, Boyer J (1995) Essais d'alimentation de la morue franche (Gadus morhua). Rapp Tech Ind Sci Halieut Aquat no. 228

Rainbow PS (1988) The significance of trace metal concentrations in decapods. Symp Zool Soc Lond 59:291-313

Rainbow PS, Amiard-Triquet C, Amiard JC, Smith BD, Best

Editorial responsibility: Otto Kinne (Editor),

Oldendorf/Luhe, Germany
SL, Nassiri Y, Langston WJ (1999) Trace metal uptake rates in crustaceans (amphipods and crabs) from coastal sites in NW Europe differentially enriched with trace metals. Mar Ecol Prog Ser 183:189-203

Rosenthal Y, Lam P, Boyle E, Thomson J (1995) Authigenic Cd enrichments in suboxic sediments: precipitation and postdepositional mobility. Earth Planet Sci Let 132:99-111

Rouleau C, Gobeil C, Tjälve H (1998) Pharmacokinetics and distribution of dietary tributyltin compared to those of methylmercury in the American plaice Hippoglossoides platessoides. Mar Ecol Prog Ser 171:275-284

Rouleau C, Gobeil C, Tjälve H (1999) Pharmacokinetics and distribution of dietary tributyltin and methylmercury in the snow crab (Chionoecetes opilio). Environ Sci Technol 33:3451-3457

Rouleau C, Gobeil C, Tjälve H (2000) Accumulation of silver from the diet in two marine benthic predators: the snow crab (Chionoecetes opilio) and the American plaice (Hippoglossoides platessoides). Environ Toxicol Chem 19: 631-637

Sainte-Marie B, Raymond S, Brêthes JC (1995) Growth and maturation of the benthic stages of male snow crab, Chionoecetes opilio (Brachyura, Majidae). Can J Fish Aquat Sci 52:903-924

Thompson RJ, Hawryluk M. (1990) Physiological energetics of the snow crab, Chionoecetes opilio. Proc Int Symp King \& Tanner Crabs, p 283-291

Tjälve H, Gottofrey J, Bjorklund I (1986) Tissue distribution of ${ }^{109} \mathrm{Cd}^{2+}$ in the brown trout (Salmo trutta) studied by autoradiography and impulse counting. Toxicol Environ Chem 12:31-45

Trudel M, Rasmussen JB (1997) Modeling the elimination of mercury by fish. Environ Sci Technol 31:1716-1722

Ullberg S, Larsson B, Tjälve H (1982) Autoradiography. In Gleen HJ (ed) Biological applications of radiotracers. CRC Press, Boca Raton, FL, p 56-108

Wallace WG, Lopez GR, Levinton JS (1998) Cadmium resistance in an oligochaete and its effect on cadmium trophic transfer to an omnivorous shrimp. Mar Ecol Prog Ser 172: 225-237

Submitted: November 30, 2000; Accepted: May 8, 2001 Proofs received from author(s): November 26, 2001 